\title{
Biological Control of a Phytosanitary Pest (Thaumatotibia leucotreta): A Case Study
}

\author{
Sean D. Moore ${ }^{1,2}$ (D)
}

Citation: Moore, S.D. Biological Control of a Phytosanitary Pest (Thaumatotibia leucotreta): A Case Study. Int. J. Environ. Res. Public Health 2021, 18, 1198. https:// doi.org/10.3390/ijerph18031198

Academic Editors: Jun Yoshinaga and Mark Gregory Robson

Received: 9 December 2020

Accepted: 23 January 2021

Published: 29 January 202

Publisher's Note: MDPI stays neutra with regard to jurisdictional claims in published maps and institutional affiliations.

Copyright: (C) 2021 by the author. Licensee MDPI, Basel, Switzerland. This article is an open access article distributed under the terms and conditions of the Creative Commons Attribution (CC BY) license (https:/ / creativecommons.org/licenses/by/ $4.0 /)$.
1 Citrus Research International, P.O. Box 5095, Walmer, Port Elizabeth 6065, South Africa; seanmoore@cri.co.za 2 Centre for Biological Control, Department of Zoology and Entomology, Rhodes University, P.O. Box 94, Makhanda 6140, South Africa

\begin{abstract}
Thaumatotibia leucotreta, known as the false codling moth, is a pest of citrus and other crops in sub-Saharan Africa. As it is endemic to this region and as South Africa exports most of its citrus around the world, T. leucotreta has phytosanitary status for most markets. This means that there is zero tolerance for any infestation with live larvae in the market. Consequently, control measures prior to exporting must be exemplary. Certain markets require a standalone postharvest disinfestation treatment for T. leucotreta. However, the European Union accepts a systems approach, consisting of three measures and numerous components within these measures. Although effective preharvest control measures are important under all circumstances, they are most critical where a standalone postharvest disinfestation treatment is not applied, such as within a systems approach. Conventional wisdom may lead a belief that effective chemical control tools are imperative to achieve this end. However, we demonstrate that it is possible to effectively control T. leucotreta to a level acceptable for a phytosanitary market, using only biological control tools. This includes parasitoids, predators, microbial control, semiochemicals, and sterile insects. Simultaneously, on-farm and environmental safety is improved and compliance with the increasing stringency of chemical residue requirements imposed by markets is achieved.
\end{abstract}

Keywords: false codling moth; citrus; systems approach; preharvest control; chemical residues

\section{Introduction}

A phytosanitary or quarantine pest is a pest of potential economic importance to an area where it is not yet present [1]. One of the prospective threats to the area lies in the importation of fresh commodities that can host the phytosanitary organism, from its native region. As global trade of susceptible fresh commodities increases, so does the risk of spread of phytosanitary pests and diseases [2]. Air passenger baggage can be another source of spread of phytosanitary organisms, but it is unclear to what extent, particularly for Lepidoptera [3]. Problems with invasive species can be further exacerbated by changes in climate, habitats, soil nitrogen levels, and atmospheric carbon dioxide levels [4]. The economic costs associated with alien species have been estimated to amount to about $5 \%$ of the world gross national product (GNP), underscoring the importance of phytosanitary protection [5]. This value would be even higher if data for all countries, species, and processes existed [6].

Phytosanitary protection is achieved through regulatory plant protection, which aims to safeguard agricultural crops from such pests and diseases [7]. Such regulations and programmes must continually be in place to prevent pests from being transported along with these commodities [7]. To this end, the International Plant Protection Convention (IPPC) was initiated in 1952, as an international treaty to prevent the spread and introduction of pests of plants and plant products, and to promote measures for their control [7]. The IPPC espouses International Standards for Phytosanitary Measures (ISPMs) that are adopted by its more than 180 member countries. The IPPC definition of a phytosanitary measure 
includes legislation, regulations, or official procedures, including treatments, to prevent the introduction and/or spread of quarantine pests [8]. A variety of methods are available to reduce the risk of invasive species accompanying commodities shipped across natural barriers to result in invasion. These are most often standalone phytosanitary treatments that result in an acceptably high reduction in risk of introduction of live organisms with the commodity [1]. A common example would be a cold disinfestation treatment that provides Probit 9 efficacy (99.9968\% mortality) [9]. However, treatments may occasionally be more complex, such as nonhost status [10], pest-free areas [11] or a systems approach [12].

Thaumatotibia leucotreta (Meyrick) (Lepidoptera: Tortricidae), known as the false codling moth, is one such phytosanitary organism [13]. It is a pest of citrus, peppers, pomegranates, peaches, and other crops in sub-Saharan Africa [14]. It is endemic to this world region and, consequently, it has phytosanitary status for most markets to which these fresh products are exported [15]. This includes Europe, the United States of America (USA), and many countries in the Far East. This status equates to a zero tolerance for the presence of the pest in the market. This is a situation that South Africa takes very seriously, as just the southern African citrus industry alone (South Africa, Zimbabwe, and Eswatini) exports around 2.1 million tons of fruit per annum, at a value of around 1.3 billion United States dollars (USD) [16]. Consequently, repercussions for inadequate compliance could be dire.

It is, therefore, imperative that $T$. leucotreta is controlled to as close to a nondetectable level as possible in the country of origin, before fruit are exported. All export markets that regulate T. leucotreta as a phytosanitary pest require a quarantine treatment of some sort [15]. For most markets, this is in the form of a standalone cold disinfestation treatment. However, for Europe (which together with the United Kingdom (UK) takes more than $40 \%$ of South Africa's export citrus), a systems approach is accepted as an effective alternative to a standalone disinfestation treatment $[13,17]$. Cold disinfestation of the large volumes of fruit exported to Europe would be impossible, not only due to logistical and infrastructural challenges, but also, more importantly, due to the fact that certain citrus types and cultivars are susceptible to chilling injury $[18,19]$ and are not suitable for export under such cold treatment conditions.

A systems approach is defined as "the integration of different risk management measures, at least two of which act independently, and which cumulatively achieve the appropriate level of protection against regulated pests" [8]. Aluja and Mangan [20] define a systems approach as "the integration of pre and postharvest practices, from the production of a commodity to its distribution and end use, that cumulatively meet predetermined requirements for quarantine security". The systems approach for T. leucotreta consists of three measures: (1) preharvest controls and measurements and post-picking sampling, inspection, and packinghouse procedures, (2) post-packing sampling and inspection, and (3) shipping conditions. All in all, Moore et al. [17] and Hattingh et al. [13] listed 13 different components within these three different measures of the systems approach. Each component serves as an important risk filter, and they cumulatively reduce the overall risk of a larva surviving in a consignment of fruit to less than that associated with the efficacy standard often used for a standalone phytosanitary treatment, being Probit 9 [13,17], i.e., no survivors when treating a population of 93,613 insects $[1,21,22]$.

Although effective preharvest control measures for phytosanitary pests are important under all circumstances, they are most critical where a standalone postharvest disinfestation treatment, which would provide adequate postharvest risk reduction on its own, is not applied. However, in order for a systems approach to succeed, every single measure and step in the system must be optimally applied; otherwise, inadequate overall risk reduction may result. Consequently, preharvest control measures are an extremely important component of the systems approach and, thus, need to be highly effective. Conventional wisdom may lead a belief that effective chemical control tools are, thus, imperative, generally being considered more effective and faster acting than their biological alternatives, particularly considering the zero-tolerance status of T. leucotreta for export markets. The downside 
of employing this rationale is that, although chemical pesticide residues spell no risk to consumers, due to strict compliance with scientifically determined maximum residue levels [23], there is evidence that their injudicious use will result in greater health risks to the user [24] and the environment [25]. Furthermore, the South African government has legislated the elimination or restriction of several insecticides since the late 1970s, fueling the need for safer alternatives and underscoring the intentions of the government to establish the so-called "South African National Bio-Economy Strategy" [26].

Confounding the belief that chemical pesticide tools may be unavoidable for control of a phytosanitary pest, for which there is no tolerance, we demonstrate here that it is possible to effectively control T. leucotreta to a level acceptable for a phytosanitary market, using only biological control tools, considering the further risk reduction added by the postharvest measures applied thereafter. Simultaneously, compliance with the increasing stringency of chemical residue requirements imposed by markets, from a regulatory perspective and even more stringently through arbitrary retailer standards, is achieved [27]. Consequently, even within the strict paradigms of organic production of fruit, the phytosanitary risk of $T$. leucotreta for export markets can be sufficiently mitigated.

Preharvest control of T. leucotreta is considered to consist of three tiers. The foundation is orchard sanitation, without which no control programme can be effective. Overlaid onto this is an areawide control technique, such as the sterile insect technique or mating disruption. Finally, orchard specific control measures are applied, such as parasitoid releases or insecticidal sprays. Preharvest monitoring is conducted using pheromone traps and by evaluating fruit infestation from designated data trees [17]. However, as T. leucotreta is now primarily a phytosanitary pest, rather than an economic pest, these monitoring tools are no longer used to determine whether intervention is warranted or not, i.e., threshold purposes [28]. This is to say that the economic losses that the pest could cause pale into insignificance with the prospect of a live larva being detected in the marketplace, for which there is zero tolerance. Consequently, contrary to their original purpose, traps are now used as a precision management tool, such as for optimizing timing of treatments [28]. Fruit infestation monitoring is used to determine whether infestation is adequately low for the orchard to be suitable for export to a market for which $T$. leucotreta is a regulated phytosanitary organism [13].

Orchard sanitation involves the regular collection and removal of infested and injured fruit from the orchard, both hanging and fallen fruit, as well as the destruction of this fruit outside of the orchard. Moore and Kirkman [29] demonstrated that weekly orchard sanitation conducted from December to June could reduce fruit infestation by an average of $75 \%$.

Here, we provide the details and efficacy of specific biological control measures, be they areawide technologies or orchard-targeted technologies, that are overlaid onto the foundation of orchard sanitation. However, before we do so, it is important that we clarify what we define as biological control. Biological control has been defined as the introduction and manipulation of natural enemies by man to control pests [30], or the use of a population of one organism to reduce the population of another organism [31]. Along with parasitoids, predators, and pathogens, the second definition implies inclusion of a technology such as the sterile insect technique (SIT). We choose to expand this definition to also include derivatives of biological organisms, specifically semiochemicals, as asserted by Mweresa et al. [32].

\section{Sterile Insect Technique}

The IPPC categorizes sterile insects as beneficial organisms [33]. Consequently, SIT can be considered a form of biological control. Furthermore, the IPPC defines SIT as a method of pest control using areawide inundative releases of sterile insects to reduce fertility of a field population of the same species [8]. The concept of SIT is that mass-reared males, sterilized through irradiation, mate with fertile wild females, which then lay only infertile eggs [34,35]. An important principle for success with SIT is achieving a sufficient 
"overflooding ratio" of sterile males to wild females [34]. The released sterile males must adequately outnumber the wild males in the release area to introduce sufficient sterility into the wild population to overcome the natural rate of increase of the wild females [36]. This overflooding ratio varies from insect to insect [34]; however, for T. leucotreta, it has been determined to be a minimum of 10 sterile to one wild male [37]. If other on-farm practices, such as orchard sanitation, are good [29], the size of successive generations of the pest is, thus, reduced [36].

SIT for T. leucotreta has been commercially implemented in the citrus and table grape industries in South Africa since 2007 [38]. It is now applied in over 18,000 ha in several different regions within three provinces throughout the country [39].

SIT was commercialized after a successful pilot trial in citrus. As a standalone treatment in a semicommercial trial, SIT reduced T. leucotreta infestation in 35 ha of Washington Navel orange orchards by $95.2 \%$, relative to an untreated control orchard [38]. These findings led to commercial implementation for control of T. leucotreta within an integrated programme, initially in the Western Cape Province (since 2007) and more recently in various other production regions, and it is proving extremely effective [40], having reduced moth catches by $99 \%$, fruit infestation by $96 \%$, and export rejections by $89 \%$ since the inception of the programme [36]. Consequently, SIT is strongly recommended as a foundational areawide technology in regions of the country where it is commercially available. Furthermore, apart from being highly effective, it is easily implementable for farmers, as the moths are released and the efficacy of the programme is monitored by the service provider, thus relieving the farmer to focus on other associated good management practices.

\section{Mating Disruption}

Mating disruption is the broadcasting of sex attractant pheromones within a crop so as to disrupt reproduction of insect pests and, thus, suppress population build up [41] Most often, this is the female sex pheromone, which disrupts males from mating. Once the pheromone is delivered, the behaviour of males is changed to achieve mating disruption by one of two ways: (1) by competitive attraction where males are diverted from orienting to females due to competing attraction of nearby false trails emanating from pheromone dispensers, or (2) by noncompetitive means, where exposure to synthetic pheromone subsequently reduces or blocks the male's ability to sense pheromone normally $[42,43]$. The latter could be achieved by negating the male's ability to respond to pheromone or by camouflaging the location of a pheromone-emitting female.

Mating disruption for T. leucotreta was introduced into South Africa in the 1990s. Products were initially based on pheromone from the oriental fruit moth, Grapholita molesta (Busck), which showed some efficacy against T. leucotreta, but insufficient to warrant commercialization of the products [44]. Subsequently, trials were conducted with the product Isomate (Shin-Etsu, Japan), using the T. leucotreta pheromone, in Navel orange orchards. Isomate, reduced T. leucotreta infestation of fruit from December to the end of April by $55 \%$ in an orchard considered to have high pest abundance, and by $75 \%$ in an orchard considered to have low pest pressure [45]. More importantly, these reductions were $86 \%$ and $95 \%$, respectively, in later evaluations shortly before harvest. In another trial, it was found that, by initiating mating disruption in October, as opposed to November, efficacy was improved from a $51 \%$ to $80 \%$ reduction in infestation [46].

Steyn [47] showed that T. leucotreta's disruption profile closely follows the predictions of the hybrid disruption profile of Miller and Gut [41], suggesting that T. leucotreta is likely disrupted competitively at low doses and noncompetitively at high doses. However, the pheromone dose required to induce this shift from competitive to noncompetitive disruption was $192 \mathrm{~g}$ per ha [47]. Unfortunately, release rates were not reported. However, this dose is higher than any of the recommended registered doses of the available mating disruption products [48]; thus, in practice, mating disruption of T. leucotreta remains competitive in nature and, therefore, most effective when the pest population is at a low level [41]. 
Four registered products are available for T. leucotreta control: Isomate FCM, Checkmate FCM-F (Suttera, Bend, OR, USA), Splat-FCM (ISCA Technologies, Riverside, CA, USA), and X-Mate (Insect Science, Tzaneen, South Africa) [46,48,49]. Isomate consists of thin polyethylene tube dispensers containing liquid sex pheromone that is released through the tube walls into the atmosphere. Checkmate is a pheromone-containing capsule suspension formulation. Splat FCM is an amorphous polymer matrix, containing pheromone. X-Mate consists of cellulose disc dispensers containing liquid sex pheromone. In regions of the country where SIT is not commercially available, mating disruption is recommended as the areawide technology of choice. Its efficacy is generally similar to that of SIT, but it requires more labour input from the grower, particularly where high-density deployment of dispensers is required, such as in the case of Isomate. Splat-FCM is applied for the farmer by the service provider, due to the specialized application equipment required.

\section{Attract-and-Kill}

Attract-and-kill technology is similar to mating disruption in that it also makes use of semiochemicals for achieving the end of controlling the pest. However, in attract-andkill, semiochemicals are used in combination with insecticides (most often), sterilants, or insect pathogens [50]. The insect responding to the semiochemical lure will encounter the insecticide or sterilizing agent, which effectively eliminates it from the population after a short time [51].

Currently, only one product based on the attract-and-kill technology is commercially available for management of T. leucotreta. The product, under the name Last Call FCM (Insect Science, Tzaneen, South Africa), consists of a blend of synthesized female sex pheromone and a pyrethroid, in the form of a gel. The combination attracts and kills male moths [46]. As with mating disruption, the technique is density-dependent, but it does not appear to be as effective as the currently available mating disruption products. Attract-and-kill technology should, therefore, not be used as the sole control method, unless the FCM population is at a low level [46].

\section{Parasitoids}

Thaumatotibia leucotreta has a range of natural enemies that suppress it in the field [14]. The most effective biological control agent against T. leucotreta is the egg parasitoid, Trichogrammatoidea cryptophlebiae Nagaraja (Hymenoptera: Trichogrammatidae) [52,53]. Where undisrupted, parasitism from naturally occurring T. cryptophlebiae reached between $80 \%$ and $100 \%$, causing from a $67 \%$ reduction in T. leucotreta infestation in Navel oranges from December to harvest to total elimination of detectable T. leucotreta infestation by harvest [46]. However, due to a number of abiotic factors, the effectiveness of T. cryptophlebiae in controlling T. leucotreta can be variable [54]. Additionally, it is highly sensitive to chemical pesticides, and injudicious selection of treatments for other pests may effectively reduce the parasitoid to negligible levels [46,55].

Initial studies on the effectiveness of T. cryptophlebiae augmentation were conducted during the 1970s and 1980s [56-58]. Schwartz [57] demonstrated up to a $75 \%$ reduction in T. leucotreta larval infestation of fruit, by releasing more than 862,000 parasitoids per hectare over a 3-month period. Newton and Odendaal [59] released 1.5-3.8 million parasitoids per hectare, divided into weekly releases. Results were variable, but larval populations were reduced by up to $61 \%$. However, such high density and frequent releases as used in both of these studies are likely to be impractical and expensive if conducted on a commercial scale. Admittedly, Newton [58] and Newton and Odendaal [59] referred to their strategy as inundative. More recently, it was shown that a more practical and affordable inoculative release approach can be effective [49]. As few as 100,000 parasitoids released per hectare $(25,000$ parasitoids per month for four consecutive months) reduced T. leucotreta infestation by up to $60 \%$ [49]. Imperative to achieving this level of success is the early initiation of releases. Releases initiated in October (spring) resulted in a greater reduction in T. leucotreta infestation than those initiated during November and December [60]. 
Historically, commercial mass rearing and augmentation of T. cryptophlebiae have been conducted by Cederberg Insectary in Citrusdal in the Western Cape Province [61] and at Zebediela Estate in Limpopo Province [62,63]. Currently, there is only one commercial insectary doing this: Vital Bugs in Limpopo Province. Consequently, augmentation of T. cryptophlebiae can only be conducted over a fairly limited area; thus, conservation of the naturally occurring population remains an attractive, practical, and universally available option. If parasitoids are available for augmentation, release is easily conducted by growers in the form of parasitized eggs placed at various well-spaced intervals throughout orchards, on a monthly basis for 4 months; thus, it is not an onerous process. However, if this cannot be initiated early in the season (spring or early summer), possibly due to the detrimental impact of chemical sprays applied against other pests, then augmentation should not be considered a viable option.

Several other parasitoids of T. leucotreta have been recorded, as listed by Newton [62] and Moore [53]. Probably the most effective of these is the larval parasitoid, Agathis bishopi (Nixon) [64-66]. However, no mass rearing or augmentation programme exists for this or any of the other species. Consequently, the only benefit that can be derived from them is through conservation, by following a biointensive integrated pest management (IPM) approach.

\section{Predators}

Ants are considered as important pests in citrus trees. The main problematic species are the pugnacious ant, Anoplolepis custodiens (Smith), and the brown house ant, Pheidole megacephala (Fabricius) [67], which do not cause direct damage to citrus plants but will defend honeydew-producing pests on citrus from their natural enemies and even transport their immature life stages to new foliage $[14,68]$. This includes pests such as citrus mealybug, Planococcus citri (Risso), soft scales (Coccus hesperidum L. and Pulvinaria aethiopica (De Lotto)), and waxy scales (Ceroplastes brevicauda Hall and C. destructor Newst.) [14,68]. Furthermore, the ants can disrupt the natural enemies of other pests, such as California red scale, Aonidiella aurantii (Mask.), causing outbreaks of these pests [69].

This emphasizes the importance of keeping ants out of citrus trees. However, on the orchard floor, ants can act as an important and effective predator of arboreal pests that pupate in the soil, such as fruit flies, Ceratitis spp. (Wied.), bollworm, Helicoverpa armigera (Hüb), and T. leucotreta [70]. Bownes et al. [70] planted pupae of these three species in a citrus orchard in plots where A. custodiens and P. megacephala had been bait-poisoned and in control plots. Pest survival was significantly lower for all three species in control plots, indicating significant predation by ants. Predation on T. leucotreta pupae was significantly higher than for the other two species. Consequently, the practice of barrier banding citrus trees to exclude ants, as opposed to poisoning, is strongly recommended to growers [14,71]. This is a labour-intensive process, including not only the deployment of the bands, but also their regular maintenance, and it would probably not be justified by a grower unless they are truly committed to an IPM philosophy.

Other predators that have been recorded include the hemipteran egg predators, Orius sp. and Orius insiduosus [62,72], the larval predator, Rhynocorus albopunctatus (Stål), and the egg/larval mite predator, Pediculoides sp. [72]. Shrews have also been implicated as predators of pupae [73]. Obviously, these generalist predators cannot be directly exploited for their benefit; however, as with ants, pursuance of an IPM programme and allowing grasses and herbs to grow between the rows of trees would lead to greater habitat complexity, increased niche diversity, and the development of a richer predator community [74].

\section{Granulovirus}

The Cryptophlebia leucotreta granulovirus (CrleGV) was first isolated from the Ivory Coast from infected T. leucotreta larvae [75]. Although the genus of the host has changed from Cryptophlebia to Thaumatotibia [76], the original name of the virus has remained unchanged [77]. Other isolates were subsequently identified, including the Cape Verde 
isolate (CrleGV-CV3) and several South African isolates (i.e., CrleGV-SA) [78-80]. The development of CrleGV as a biopesticide in South Africa began in 1998, leading to its evaluation in several field trials from 2000 [53,81]. Two different South African isolates have since been formulated and registered as the commercial products Cryptogran (River Bioscience, South Africa), Cryptex, and Gratham (both Andermatt Biocontrol, Switzerland) for field application [27]. These are registered at rates equivalent to $5 \times 10^{12}$ occlusion bodies (OBs) / ha in the case of Cryptogran and $6.6 \times 10^{11} \mathrm{OBs} /$ ha in the case of the other two products.

CrleGV has been extensively tested in the field for many years with more than 50 trials completed, and it has been used commercially over tens of thousands of hectares annually for almost two decades $[27,77,81]$. Trial results show that applications of CrleGV have consistently led to significant reductions in fruit infestation in relation to untreated controls. The highest reduction in infestation was reported to be $92 \%$, while the lowest was $27 \%$ [77]. While such variability in levels of suppression may be undesirable, this underscores the importance of an IPM programme consisting of several technologies to cumulatively reduce pest levels. Several of the trials also showed that the addition of an adjuvant such as molasses often significantly improved the efficacy of the treatment, frequently achieving levels of control similar to the chemical alternatives and, in some cases, outperforming certain chemicals [77]. In one case, this was attributed to possible resistance in the T. leucotreta population [82]; however, in others, it was simply superior efficacy.

The granulovirus products are probably the most widely used of all products for T. leucotreta control, including the chemical insecticides, bearing testimony to not only their efficacy, but also their affordability and ease of application. The products are applied using conventional pesticide spray equipment and can be tank-mixed with other pesticides without risk of compromised efficacy.

Despite field performance generally being good, further improvement of field efficacy is being sought, through combining isolates of the same virus. As discussed by LópezFerber et al. [83], the use of pure genotypes or low-genetic-diversity isolates in products, would be less effective than products containing virus with greater genetic heterogenicity. Preliminary field trials, combining two regionally distinct CrleGV isolates, have already been reported to yield better results than those achieved with the standard single isolate CrleGV product [84].

Probably the most important shortcoming of baculoviruses is their sensitivity to ultraviolet (UV) degradation and, hence, rapid breakdown in the presence of direct sunlight [85-87]. Consequently, another means by which improvement in the efficacy of CrleGV is being sought is through selection for UV resistance. By exposing virus samples to conditions simulating normal daylight $\mathrm{UV}$, propagating these in larvae and re-exposing them to UV, after five cycles, $\mathrm{LC}_{50}$ (the concentration required to kill $50 \%$ of sampled individuals in a population) and $\mathrm{LC}_{90}$ (the concentration required to kill $90 \%$ of sampled individuals in a population) were reduced $1226-$ and 563 -fold [88,89]. This suggests successful isolation of UV-resistant virus, confirmed by associated genetic changes identified in 14 single-nucleotide polymorphisms (SNPs) [88]. The genetic stability of this selection and its efficacy in the field must still be confirmed.

\section{Nucleopolyhedrovirus}

Recently, the first nucleopolyhedrovirus (NPV) in the Grapholitini tribe of Tortricidae was discovered [90], being the NPV of the litchi moth, Cryptophlebia peltastica (Meyrick), an African pest species [91]. The Cryptophlebia peltastica NPV (CrpeNPV) was isolated and characterized genetically and biologically, demonstrating not only that it is a unique virus [90], but also that its virulence extends beyond its homologous host. In laboratory bioassays, CrpeNPV was found to be similarly virulent to the codling moth, Cydia pomonella (L.), and T. leucotreta as to C. peltastica and marginally more virulent than the homologous GVs of these species [92,93]. 
Preliminary field trials have already been conducted with CrpeNPV against T. leucotreta in citrus at rates of between $5 \times 10^{11}$ and $5 \times 10^{13} \mathrm{OBs} /$ ha [94]. Very promising results were recorded, with infestation being reduced by over $90 \%$ with a single application in one case [94].

CrpeNPV has also been evaluated for use in combination with CrleGV, with some mixtures identified to have a synergistic effect, resulting in an increase in insecticidal activity $[95,96]$. However, additional research is still needed. The commercial formulation of CrpeNPV, either on its own or in combination with another virus such as CrleGV, could prove invaluable to future IPM programmes for T. leucotreta, not only on citrus, but also even more so on crops where more than one grapholitinid is a pest, such as on macadamias, where T. leucotreta, C. peltastica, and T. batrachopa (Meyrick) can be a problem.

The appearance of a CrpeNPV-based product on the market is imminent. It can be expected that its mode and ease of application and its affordability will be as for the granulovirus products.

\section{Entomopathogenic Fungi}

Laboratory bioassays against final instar T. leucotreta identified three entomopathogenic fungal (EPF) isolates with the greatest pesticidal potential, two Metarhizium anisopliae (Metchnikoff) Sorokin (Hypocreales: Clavicipitaceae) isolates and one Beauveria bassiana (Balsamo) Vuillemin (Hypocreales: Cordycipitaceae) isolate [97,98]. All three isolates were originally identified from soil samples collected from citrus orchards and surrounding refugia within citrus growing regions of the Eastern Cape Province of South Africa [99]. Results of sand-conidial bioassays indicated that fungal-induced mycosis of T. leucotreta of greater than $80 \%$ was achievable when applied at a rate of $1 \times 10^{6}$ conidia/g soil with average $\mathrm{LC}_{50}$ values of $6.26 \times 10^{5}, 1.92 \times 10^{6}$, and $1.98 \times 10^{5}$ conidia/mL for the selected M. anisopliae and B. bassiana isolates $[97,98]$. These isolates also showed good persistence under semi-field conditions. All three isolates were recovered from within the upper $5 \mathrm{~cm}$ soil surface over 6 months after application in the field [100].

Thereafter, large-scale field trials were conducted with application of the three selected isolates to the soil surface underneath the canopy of citrus trees at rates ranging from $1 \times 10^{12}$ to $1 \times 10^{14}$ spores/ha, using a commercial tractor-drawn spray machine [101]. Weekly fruit drop surveys were conducted to determine the mean T. leucotreta-infested fruit per tree per week and any percentage reduction in T. leucotreta infestation that resulted from fungal application. In comparison to the control treatments, all three isolates used were capable of reducing T. leucotreta infestation in the field. The B. bassiana isolate performed best, with an average reduction in T. leucotreta infestation of $82 \%$, measured over a 32-week period after a single application in spring. Over time, the reduction in T. leucotreta infestation remained constant for the B. bassiana isolate throughout the trial period, but declined for both M. anisopliae isolates (54.01\% to $35.02 \%$ ) and (47.39\% to $27.65 \%$ ) from 10 weeks after treatment to 32 weeks after treatment [101].

Commercial development of these isolates for application against the soil-dwelling life stages of T. leucotreta is underway. In the meantime, two other isolates of B. bassiana are already registered for use against T. leucotreta on citrus [102]. However, this is as a foliar application, targeted against the eggs and neonate larvae. Efficacy with this mode of application is not always satisfactory, due mainly to the UV sensitivity of the fungi and, hence, the short residual activity [102]. Although fairly extensive general use is made of these existing EPF products, their specific use against T. leucotreta is not commonplace, due largely to their limited efficacy. Consequently, development of an effective formulation to overcome UV sensitivity and other environmental hurdles is desirable in order to achieve more consistent efficacy with foliar application. In the meantime, efficacy can be optimized through accurate timing of applications with peaks in egg laying and frequent reapplication [103].

It is expected that, once the soil-targeted formulations become available, the use of EPF against T. leucotreta will increase, as not only will they be more effective, but 
application through the irrigation (microsprinkler) system will also be even easier than conventional spraying.

\section{Entomopathogenic Nematodes}

Malan et al. [104] and Steyn et al. [105] demonstrated in laboratory bioassays that several locally collected species of entomopathogenic nematodes (EPNs) were all highly virulent to $T$. leucotreta larvae at rates as low as 20 infective juveniles (IJs) $/ \mathrm{cm}^{2}$. These were Steinernema sp., Heterorhabditis bacteriophora, S. yirgalemense, S. khoisanae, H. zealandica, Heterorhabditis sp., Heterorhabditis baujardi, and Steinernema litchii. These results provided strong evidence of noteworthy potential of the EPNs for the control of T. leucotreta in the field. Consequently, Malan and Moore [106] conducted small-scale field trials to examine infection of sentinel T. leucotreta larvae with EPNs in a citrus orchard environment. Heterorhabditis bacteriophora, H. zealandica, and S. khoisanae were applied at concentrations ranging from 5 to $80 \mathrm{IJs} / \mathrm{cm}^{2}$. The Heterorhabditis species were the most effective, with up to $90 \%$ infection of T. leucotreta larvae and detectable persistence for 49 days, albeit at a reduced level.

These results were confirmed with significant efficacy recorded with $S$. yirgalemense and S. jeffreyense against T. leucotreta in semi-field trials in other crops (vineyards, avocado, litchi, and macadamia), using a similar methodology $[47,107]$.

Consequently, large commercial-scale field trials were conducted in citrus orchards in the Eastern Cape, Western Cape, and Mpumalanga provinces of South Africa from 2011 to 2013, geared toward directly testing the ability of EPNs to achieve pest reduction and crop protection in the orchards [108]. Heterorhabditis bacteriophora and S. feltiae were applied underneath tree canopies in large orchards, using tractor-drawn spray machinery or through the irrigation system. Successful control was recorded in several trials, with EPN infection of larvae frequently exceeding $80 \%$ and larval infestation of fruit being reduced by up to $88 \%$, with persistence recorded for up to 5 months [108]. However, results were sometimes disappointing, with the main cause being suboptimal soil moisture, a factor that can be managed.

Furthermore, naturally occurring EPNs (H. zealandica) were shown to reduce fruit infestation by T. leucotreta by $59 \%$ in orchards where they were not suppressed by the nematicide, cadusafos, emphasizing the importance of EPN conservation in orchards [109].

As a result of these positive results, an H. bacteriophora-based product (Cryptonem) (River Bioscience, South Africa) was registered for use against T. leucotreta in citrus [102]. This registration was unfortunately later suspended, due to unfounded regulatory concerns about nontarget effects $[110,111]$. However, the registration was recently revived, and registration of a new S. feltiae-based product has also been approved. This is an extremely positive development, as it now provides registered and commercially available biological products for targeting of the previously ignored soil-borne life stage of T. leucotreta [108].

It remains to be seen how extensively these products are used once they become commercially available. Their mode of application will be through the irrigation system as described for the EPF products and, thus, very user-friendly. However, efficacy, perception of efficacy, and cost will also affect use. Generally, our trials have shown more consistent efficacy with EPF than EPN against the soil-dwelling life stages of T. leucotreta.

\section{Discussion}

Several different biological control technologies are available or under development for use against the phytosanitary pest, T. leucotreta on citrus in southern Africa (Table 1). These include the sterile insect technique, mating disruption, attract-and-kill, parasitoids for augmentation, baculoviruses, entomopathogenic fungi, and entomopathogenic nematodes. There is a total of 13 such products currently available with more that are imminent. This outnumbers the registered and available chemical active ingredients for management of this pest, i.e., spinetoram, chlorantraniliprole, triflumuron, teflubenzuron, fenpropathrin, cypermethrin, methoxyfenozide, and emamectin benzoate [46,49]. Additionally, the insect 
growth regulators (IGRs), triflumuron and teflubenzuron, have limited usefulness due to stringent residue restrictions from most export markets and the development of resistance by T. leucotreta [82]. The use of the pyrethroids, fenpropathrin and cypermethrin, is undesirable due to their extreme harmfulness to nontarget organisms [55], including the exceptionally effective T. leucotreta egg parasitoid, T. cryptophlebiae [46,59]. This leaves only the newer-generation products, namely, spinetoram, chlorantraniliprole, methoxyfenozide, and emamectin benzoate. Although these products can be highly effective (e.g., [77]), they are expensive and their use shortly before harvest may lead to residue problems in the market.

Table 1. Biopesticides developed or under development for control of Thaumatotibia leucotreta in citrus in South Africa.

\begin{tabular}{|c|c|c|c|c|c|c|}
\hline \multirow{2}{*}{$\begin{array}{c}\text { Technology/Organism } \\
\text { Category }\end{array}$} & \multirow{2}{*}{ Active Ingredient } & \multirow{2}{*}{ Product Name } & \multicolumn{2}{|c|}{ Commercial Company } & \multirow{2}{*}{$\begin{array}{l}\text { Life Stage } \\
\text { Targeted }\end{array}$} & \multirow{2}{*}{$\begin{array}{c}\text { Product } \\
\text { Commercially } \\
\text { Available }\end{array}$} \\
\hline & & & Manufacturer & Local Supplier & & \\
\hline $\begin{array}{l}\text { Sterile insect } \\
\text { technique }\end{array}$ & $\begin{array}{c}\text { Sterile male and } \\
\text { female T. leucotreta } \\
\text { adults }\end{array}$ & Xsit FCM SIT & Xsit & Xsit & Adult & Yes \\
\hline \multirow{4}{*}{ Mating disruption } & \multirow{5}{*}{$\begin{array}{l}\text { T. leucotreta female sex } \\
\text { pheromone }{ }^{1,2}\end{array}$} & Isomate FCM & Shin-Etsu & Nulandis & Adult male & Yes \\
\hline & & RB Splat FCM & $\begin{array}{c}\text { ISCA } \\
\text { Technologies }\end{array}$ & $\begin{array}{c}\text { River } \\
\text { Bioscience }\end{array}$ & Adult male & Yes \\
\hline & & $\begin{array}{l}\text { Checkmate } \\
\text { FCM-F }\end{array}$ & Suterra & Chempac & Adult male & Yes \\
\hline & & X-Mate FCM & Insect Science & Insect Science & Adult male & Yes \\
\hline Attract and kill & & Last Call FCM & Insect Science & Insect Science & Adult male & Yes \\
\hline Parasitoids & $\begin{array}{l}\text { Trichogrammatoidea } \\
\text { cryptophlebiae }\end{array}$ & Tri-mX & Vital Bugs & Vital Bugs & Egg & Yes \\
\hline \multirow{4}{*}{ Baculovirus } & \multirow{3}{*}{$\begin{array}{l}\text { Cryptophlebia } \\
\text { leucotreta } \\
\text { granulovirus } \\
(\text { CrleGV) }\end{array}$} & Cryptogran & $\begin{array}{c}\text { River } \\
\text { Bioscience }\end{array}$ & $\begin{array}{c}\text { River } \\
\text { Bioscience }\end{array}$ & $\begin{array}{l}\text { Neonate } \\
\text { larva }\end{array}$ & Yes \\
\hline & & Cryptex & Andermatt & Madumbi & $\begin{array}{l}\text { Neonate } \\
\text { larva }\end{array}$ & Yes \\
\hline & & Gratham & Andermatt & Chempac & $\begin{array}{l}\text { Neonate } \\
\text { larva }\end{array}$ & Yes \\
\hline & $\begin{array}{l}\text { Cryptophlebia } \\
\text { peltastica nucleopoly- } \\
\text { hedrovirus } \\
\text { (CrpeNPV) }\end{array}$ & & $\begin{array}{c}\text { River } \\
\text { Bioscience }\end{array}$ & $\begin{array}{l}\text { River } \\
\text { Bioscience }\end{array}$ & $\begin{array}{l}\text { Neonate } \\
\text { larva }\end{array}$ & No \\
\hline \multirow{3}{*}{$\begin{array}{l}\text { Entomopathogenic } \\
\text { fungi }\end{array}$} & Beauveria bassiana & Broadband & BASF & BASF & $\begin{array}{c}\text { Egg and } \\
\text { neonate larva }\end{array}$ & Yes \\
\hline & & Eco-Bb & $\begin{array}{l}\text { Plant Health } \\
\text { Products }\end{array}$ & Madumbi & $\begin{array}{c}\text { Egg and } \\
\text { neonate larva }\end{array}$ & Yes \\
\hline & $\begin{array}{l}\text { Metarhizium } \\
\text { anisopliae }\end{array}$ & & $\begin{array}{l}\text { River } \\
\text { Bioscience }\end{array}$ & $\begin{array}{c}\text { River } \\
\text { Bioscience }\end{array}$ & Final instar & No \\
\hline \multirow{2}{*}{$\begin{array}{l}\text { Entomopathogenic } \\
\text { nematodes }\end{array}$} & $\begin{array}{l}\text { Heterorhabditis } \\
\text { bacteriophora }\end{array}$ & Cryptonem & e-nema & $\begin{array}{c}\text { River } \\
\text { Bioscience }\end{array}$ & $\begin{array}{c}\text { All } \\
\text { soil-dwelling } \\
\text { life stages }\end{array}$ & Yes \\
\hline & Steinernema feltiae & Nemapom & e-nema & $\begin{array}{l}\text { River } \\
\text { Bioscience }\end{array}$ & $\begin{array}{c}\text { All } \\
\text { soil-dwelling } \\
\text { life stages }\end{array}$ & No \\
\hline
\end{tabular}

${ }^{1}$ All products have two or three of the following isomers: (E)-7-dodecenyl acetate, (E)-8-dodecenyl acetate, (Z)-8-dodecenyl acetate, and (E/Z)-8-dodecenol. ${ }^{2}$ Plus permethrin in the case of Last Call FCM.

There is a general perception that biopesticides may not be as effective as their chemical alternatives [27]. However, Moore et al. [77] have shown in many cases that the granulovirus, CrleGV, for example, can be as effective as, or even more effective, than its chemical counterparts for T. leucotreta control. Similarly, another virus, the nucleopolyhedrovirus, CrpeNPV, was able to reduce T. leucotreta infestation to a comparable extent, i.e., by up to $90 \%$ [94]. SIT has been shown to reduce T. leucotreta fruit infestation by $95 \%$ in a single trial [38] and by $96 \%$ in an entire treated region of several thousand hectares over time [36]. Chemical control has rarely been reported to achieve this level of efficacy and certainly does not have the sustainability of a biological approach. Mating disruption has been reported to reduce T. leucotreta by up to $95 \%$ shortly before harvest $[45,46]$. Thauma- 
totibia leucotreta infestation was shown to be reduced by up to $75 \%$ through augmentation of an egg parasitoid [57], by $82 \%$ with the application of EPF to the orchard soil [101], and by $88 \%$ using EPNs [108].

These are obviously best-case scenarios, and efficacy with biologicals does tend to be more variable than with chemicals $[27,112]$. However, even if the efficacy of each intervention is well below the maximum potential efficacy of the treatment, T. leucotreta control has become far more sophisticated than was previously the case, more specifically entailing the combination of various control measures as opposed to relying on a single treatment option [46]. The levels of control achieved should, therefore, be seen as the sum of the efficacy of all the measures used in combination or in sequence. For example, if a grower practices orchard sanitation, applies EPNs to the soil, applies two foliar virus sprays, and uses mating disruption (i.e., five different treatments), the level of control may conservatively be $50 \%$, on top of $50 \%$, on top of $50 \%$, and so on. Whereas each treatment in isolation may not be considered adequate where the population level is high or when producing for a phytosanitarily sensitive market, the combination would provide a satisfactory cumulative control of approximately 97\% [46]. Furthermore, withholding from chemical intervention will effectively conserve natural enemies resident in the orchard, thus naturally augmenting this level of control.

Consequently, the standard T. leucotreta control programme recommended for citrus in South Africa is a foundation of regular diligent orchard sanitation, overlaid with an areawide control technology, such as SIT or mating disruption, and sprays (preferably virus products) applied at appropriate intervals, usually coinciding with peaks in egg hatch, forecast by moth flight peaks [49]. Control measures for T. leucotreta for the following season should be initiated immediately on completion of harvesting of the previous season, by collecting, removing, and destroying all fruit remaining in the orchard, both those hanging and those dropped to the ground [29]. This will remove not only all potentially infested fruit remaining in the orchard, but also the bridge for transfer of the T. leucotreta population from one season's crop to the next, particularly if there is a period of at least 3 months between harvest and fruit set, the maximum development period for the soildwelling life stages of T. leucotreta during winter [113]. The recommended areawide control measure must be initiated early in the season (spring), while the T. leucotreta population is still low, after suppression by winter conditions, and before population numbers can start to build. This is because all of these technologies are negatively density-dependent for optimal efficacy to be achieved $[36,41]$. Approaches such as release of egg parasitoids and application of EPF or EPN to the soil should also be initiated this early in the season for optimal efficacy $[60,101,108]$. Virus sprays can be applied at any time during the season, as they leave no detectable residues on fruit and have no undesirable nontarget effects [27]. However, as residual efficacy is detrimentally affected by direct exposure to UV radiation [85-87], application of sprays should ideally be timed with a peak in T. leucotreta egg hatch, which can be fairly accurately estimated through monitoring of male adult activity in pheromone traps [28]. Furthermore, as T. leucotreta is multivoltine (at least six generations per year in southern African conditions) [62] and does not diapause [114], generations are not distinctly separated from one another. As the season progresses, the overlap of generations tends to increase and it becomes more difficult to distinguish generational peaks. Consequently, detection of these generational peaks and, thus, ideal timing of a virus spray is easier during the first half of the season, after the synchronizing effect of winter.

As T. leucotreta is regulated as a phytosanitary pest by most export markets, meaning that there is zero tolerance for the pest, there are no thresholds dictating when control measures should be applied and when it is not considered necessary. Pheromone trapbased thresholds were recommended several years ago when T. leucotreta was primarily considered an economic pest, but this is no longer the case [28]. However, according to the T. leucotreta systems approach protocols, if a very low fruit infestation threshold is surpassed in fruit from the designated data trees in an orchard during the final 12 weeks 
before harvest, an additional corrective control measure must be applied, regardless of what control measures were previously applied [13]. If this low threshold is surpassed during the last 4 weeks before harvest, the fruit need to either be subjected to a more stringent postharvest handling protocol or be withdrawn from export to a sensitive market [13].

The full T. leucotreta management programme that a grower chooses will ultimately depend on several factors: the grower's assessment of the severity of the problem, the sensitivity of the market to the presence of T. leucotreta in the fruit, the severity of the postharvest handling conditions available and selected, the value of the particular cultivar, and the anticipated prices in the market place. None of these biological methods of control are incompatible with one another, possibly, surprisingly, not even mating disruption and SIT. In fact, superior efficacy was recorded against the closely related apple pest, C. pomonella, by combining these technologies [115]. Consequently, any of these technologies can be used in combination and/or in sequence in order to achieve the best result.

Adoption of a judiciously constructed biological control programme will lead to a sufficiently suppressed level of $T$. leucotreta occurrence at harvest to be suitable for export of fruit to a market that regulates T. leucotreta as a phytosanitary organism and exercises zero tolerance for the occurrence of any live larvae in a consignment of fruit. This threshold tolerance at harvest (as opposed to zero tolerance) is acceptable, as the fruit will still be subjected to several further steps that together will reduce the occurrence of T. leucotretainfested fruit to a negligible level $[13,17]$. This includes (1) postharvest fruit inspections for T. leucotreta infestation on delivery at the packinghouse, to determine subsequent handling requirements, (2) packinghouse grading of fruit on the packing line, involving the removal of any fruit appearing to be damaged or infested, (3) inspection of a $2 \%$ fruit sample per pallet of fruit packed for export and rejection of any pallet in which live T. leucotreta was detected, (4) prescription of shipping condition options for each export consignment according to compliance with preceding steps of the systems approach, and (5) official phytosanitary certification of compliant consignments.

Moore et al. [17] calculated the overall risk mitigation efficacy of the systems approach as the proportion of fruit that could be infested with T. leucotreta after application of the systems approach, determining that it was 6-38 times less than the proportion associated with the Probit $9\left(p \leq 3.2 \times 10^{-5}\right)$ standard for a standalone cold treatment, being three survivors in 100,000 at the $95 \%$ confidence level, proven by zero survivors in 93,613 insects, i.e., a $99.9968 \%$ mortality [1]. Hattingh et al. [13] later reported improvements to the systems approach for T. leucotreta, still concluding that the maximum potential proportion of fruit that may be infested with live T. leucotreta after application of the improved systems approach is no greater than the proportion of fruit that may be infested after application of a Probit 9 efficacy postharvest disinfestation treatment to fruit with a $2 \%$ pretreatment infestation. Additionally, they determined that the probability of a mating pair surviving the systems approach, as a more biologically meaningful alternative to the quantification of a mortality level such as the Probit 9 reference, was far lower. This reasoning would be strengthened by the fact that T. leucotreta is a poor invader [116,117], having only been established in two regions where it is not indigenous, i.e., the Western Cape of South Africa $[40,118]$ and Israel [119]. This is despite large volumes of T. leucotreta-susceptible produce being exported throughout the world for more than 100 years [120].

Another assessment that must be made is that of the cost of a biological programme versus a conventional programme, as this too will influence a grower's decision on what products to use. The cost of the biological products range from 62-309 USD per hectare per application or per programme with the product, whereas the cost of the chemical products ranges from 73-382 USD per hectare (Table 2). The areawide approaches, SIT, mating disruption, and attract-and-kill, are understandably expensive, as their efficacy spans several months, covering most of the growing season, as is also the case with parasitoid augmentation. However, the chemical sprays are on average a lot more expensive than the biological sprays. In comparing programmes, no programme is likely to be entirely chemical, as the areawide approach that is so strongly recommended as a foundational 
component of the T. leucotreta management programme only has the option of biological tools. Consequently, if a grower is in a region where SIT is not available, they have a choice of overlaying a biological approach (most likely virus sprays) or a chemical approach onto mating disruption. The average cost per hectare of a virus spray is 80 USD, whereas the average cost of a chemical spray is 243 USD. This is not considering the older chemistry, such as pyrethroids and some IGRs, whose use is discouraged or even restricted through residue intolerance by markets. Although the duration of control can be expected to be relatively similar between virus and chemical treatments, on average, it can be expected that the efficacy of a chemical treatment might be more consistent than that of a virus spray. However, the chemical treatments are more likely to have some detrimental effect on natural enemies, such as the parasitoids of T. leucotreta $[46,55]$, thus eroding natural control, whereas this will not happen with the biological treatments. Consequently, there is little justification for preferring the chemical pesticides, particularly considering their higher cost.

Table 2. Cost comparison between biopesticides and chemical pesticides for control of T. leucotreta in citrus in South Africa. Prices were obtained from three local suppliers and averaged where necessary.

\begin{tabular}{|c|c|c|c|}
\hline $\begin{array}{l}\text { Biological or } \\
\text { Chemical }\end{array}$ & Product $^{1}$ & $\begin{array}{l}\text { Cost per ha per Application } \\
\text { or Programme } 2 \text { (USD) }\end{array}$ & $\begin{array}{c}\text { Duration of Control } \\
\text { per Application }{ }^{3}\end{array}$ \\
\hline \multirow{12}{*}{ Biological } & $\begin{array}{c}\text { Sterile insect } \\
\text { technique (SIT) }\end{array}$ & 309 & 6 months \\
\hline & Isomate & 287 & 6 months \\
\hline & Splat & 280 & 6 months \\
\hline & Checkmate & 323 & 6 months \\
\hline & X-Mate & 304 & 6 months \\
\hline & Last Call & 231 & 5 months \\
\hline & Tri-mX & 241 & Season-long 4 \\
\hline & Cryptogran & 81 & 4-17 weeks \\
\hline & Cryptex & 80 & $<$ Cryptogran 5 \\
\hline & Gratham & 80 & $<$ Cryptogran 5 \\
\hline & Broadband $^{6}$ & 64 & 10 days \\
\hline & Eco-Bb ${ }^{6}$ & 62 & 10 days \\
\hline \multirow{4}{*}{ Chemical } & Delegate & 73 & 4 weeks \\
\hline & Runner & 250 & 4 weeks \\
\hline & Coragen & 382 & 6-8 weeks \\
\hline & Warlock & 200 & 7-10 days \\
\hline
\end{tabular}

${ }^{1}$ See Table 1 for product details. ${ }^{2}$ This is the cost of a single application, except in the case of the mating disruption products and the attract-and-kill product, which are registered to be applied as a programme, consisting of more than one application. ${ }^{3}$ Duration of control was obtained from the product label, except in the case of the virus products, which were obtained from Moore et al. [77]. ${ }^{4}$ Difficult to give a duration of control, as augmentation is inoculative and, consequently, it will take some time for parasitoids to build up to an influential level. ${ }^{5}$ Duration of residual efficacy is deemed to be shorter with these two virus products, as their amount of active ingredient per $h$ is $7.6 \times$ less than that of Cryptogran. ${ }^{6}$ Dosage, duration of efficacy, and number of applications are not very clearly defined in the product recommendations on the label. Consequently, cost could be higher than listed.

Moore and Jukes [27] argue that the most compelling reason for using biopesticides and biological control agents is the argument of compulsion, rather than attraction. Tremendous pressure is being placed on the use of chemical insecticides [121,122]. Pesticide review programmes, increased stringency in the regulation of maximum residue levels (MRLs), arbitrary retailer residue restrictions, and growing public sentiment are contributing to this pressure [23]. The European Union (EU) has placed IPM centrally within its 2009 Sustainable Use Directive on pesticides [123]. EU member states were required to adopt national action plans for IPM by December 2012, and the implementation of these was reviewed in December 2018. This was most recently followed by the announcement of the European Green Deal, which aims to reduce net emission of greenhouse gasses in the region to zero by 2050 and by 50\% by 2030 [124]. This will be done through substantial investment in environmentally friendly technologies. Similar directives and requirements might be 
expected for agricultural produce being imported into the EU, and other countries in the world may well follow the EU lead. Consequently, it is becoming more difficult for farmers to pursue a conventional chemical control programme, particularly if their produce is sold through high-end retailers or exported to OECD (Organisation for Economic Cooperation and Development) markets [27].

Consequently, in conclusion, it is not only possible to control the phytosanitary pest, T. leucotreta, for which export markets exercise zero tolerance, using exclusively biological means of control, but also highly desirable and beneficial for human (pesticide application) and environmental safety and in order to maintain the exportability of the fruit in a market that is increasingly chemical residue-intolerant.

Funding: This research received no external funding.

Institutional Review Board Statement: Not applicable.

Informed Consent Statement: Not applicable.

Data Availability Statement: Not applicable.

Acknowledgments: Tim Grout is thanked for reviewing an earlier version of this manuscript. Tammy Marsberg is thanked for assisting with reference formatting.

Conflicts of Interest: The author declares no conflict of interest.

\section{References}

1. Follett, P.A.; Neven, L.G. Current trends in quarantine entomology. Ann. Rev. Entomol. 2006, 51, 359-385. [CrossRef] [PubMed]

2. Schwalbe, C.P.; Hallman, G.J. An appraisal of forces shaping the future of regulatory entomology. In Invasive Arthropods in Agriculture: Problems and Solutions; Hallman, G.J., Schwalbe, C.P., Eds.; Science Publishers: Enfield, UK, 2002 ; pp. $425-433$.

3. EPP.O (European and Mediterranean Plant Protection Organisation). Pest Risk Analysis for Thaumatotibia leucotreta, App.endix 5; EPP.O: Paris, France, 2013. Available online: http://www.epp.o.int/QUARANTINE/Pest_Risk_Analysis/PRA_intro.htm (accessed on 4 December 2020).

4. Thuiller, W.; Richardson, D.M.; Midgley, G.F. Will Climate Change Promote Alien Plant Invasions? In Biological Invasions. Ecological Studies (Analysis and Synthesis); Nentwig, W., Ed.; Springer: Berlin/Heidelberg, Germany, 2008; Volume 139, pp. 197-211. [CrossRef]

5. Nentwig, W. Biological Invasions: Why it Matters. In Biological Invasions. Ecological Studies (Analysis and Synthesis); Nentwig, W., Ed.; Springer: Berlin/Heidelberg, Germany, 2008; Volume 193, pp. 1-6. [CrossRef]

6. Pimentel, D.; Pimentel, M.; Wilson, A. Plant, Animal, and Microbe Invasive Species in the United States and World. In Biological Invasions. Ecological Studies (Analysis and Synthesis); Nentwig, W., Ed.; Springer: Berlin/Heidelberg, Germany, 2008; Volume 193, pp. 315-330. [CrossRef]

7. Hallman, G.J. Phytosanitary measures to prevent the introduction of invasive species. In Biological Invasions; Nentwig, W., Ed.; Springer: Berlin/Heidelberg, Germany, 2008; pp. 367-384. [CrossRef]

8. FAO (Food and Agriculture Organisation of the United Nations). Glossary of Phytosanitary Terms (ISPM 5). Secretariat of the International Plant Protection Convention (IPP.C); FAO: Rome, Italy, 2019; Available online: https:/ /www.ipp.c.int/en/publications / glossary-phytosanitary-terms / (accessed on 28 October 2020).

9. Moore, S.D.; Kirkman, W.; Stephen, P.R.; Albertyn, S.; Love, C.N.; Grout, T.G.; Hattingh, V. Development of an improved postharvest cold treatment for Thaumatotibia leucotreta (Meyrick) (Lepidoptera: Tortricidae). Postharvest Biol. Technol. 2017, 125, 188-195. [CrossRef]

10. APP.PC (Asia and Pacific Plant Protection Commission). Guidelines for the Confirmation of Non-Host Status of Fruit and Vegetables to Tephritid Fruit Flies. Regional Standards for Phytosanitary Measures No. 4; Regional Office for Asia and the Pacific (RAP) Publication 2005/27; APP.PC: Bangkok, Thailand, 2015.

11. FAO. Requirements for the Establishment of Pest Free Areas. International Standard for Phytosanitary Measures No. 4; Published by FAO on Behalf of the Secretariat of the International Plant Protection Convention; IPP.C: Rome, Italy, 2017; p. 9.

12. FAO. The Use of Integrated Measures in a Systems App.roach for Pest Risk Management. International Standard for Phytosanitary Measures No.14; Published by FAO on Behalf of the Secretariat of the International Plant Protection Convention; IPP.C: Rome, Italy, 2017; p. 12.

13. Hattingh, V.; Moore, S.D.; Kirkman, W.; Goddard, M.; Thackeray, S.R.; Peyper, M.; Sharp, G.; Cronjé, P.; Pringle, K. An Improved Systems App.roach as a Phytosanitary Measure for Thaumatotibia leucotreta (Lepidoptera: Tortricidae) in Export Citrus Fruit From South Africa. J. Econ. Entomol. 2020, 113, 700-711. [CrossRef]

14. Grout, T.G.; Moore, S.D. Insects of Cultivated Plants and Natural Pastures in Southern Africa; Prinsloo, G.L., Uys, G.M., Eds.; Entomological Society of Southern Africa: Pretoria, South Africa, 2015; pp. 447-501. 
15. SA DALRRD (South African Department of Agriculture Forestry and Fisheries). Special Export Protocols/Programmes/Directives. 2015. Available online: https://www.dalrrd.gov.za/Branches/Agricultural-Production-Health-Food-Safety/Plant-Health/ Exporting-from-SA/Special-export-protocols. (accessed on 15 September 2020).

16. CGA. Citrus Growers' Association. Key Industry Statistics; CGA: Hillcrest, South Africa, 2019.

17. Moore, S.D.; Kirkman, W.; Hattingh, V. Verification of inspection standards and efficacy of a systems app.roach for Thaumatotibia leucotreta (Lepidoptera: Tortricidae) for export citrus from South Africa. J. Econ. Entomol. 2016, 109, 1564-1570. [CrossRef]

18. Cronjé, P.J.R. Postharvest Rind Disorders of Citrus Fruit; Citrus Research International: Nelspruit, South Africa, 2007.

19. Lafuente, M.T.; Zacarias, L.; Martínez-Téllez, M.A.; Sanchez-Ballesta, M.T.; Granell, A. Phenylalanine ammonia-lyase and ethylene in relation to chilling injury as affected by fruit age in citrus. Postharvest Biol. Technol. 2003, 29, 309-318. [CrossRef]

20. Aluja, M.; Mangan, R.L. Fruit fly (Diptera: Tephritidae) host status determination: Critical conceptual, methodological, and regulatory considerations. Ann. Rev. Enotmol. 2008, 53, 473-502. [CrossRef] [PubMed]

21. Couey, H.M.; Chew, V. Confidence limits and sample size in quarantine research. J. Econ. Entomol. 1986, 79, 887-890. [CrossRef]

22. Follett, P.A.; Hennessey, M.K. Confidence limits and sample size for determining nonhost status of fruits and vegetables to tephritid fruit flies as a quarantine measure. J. Econ. Entomol. 2007, 100, 251-257. [CrossRef]

23. Lacey, L.A.; Grzywacz, D.; Shapiro-Ilan, D.I.; Frutos, R.; Brownbridge, M.; Goettel, M.S. Insect pathogens as biological control agents: Back to the future. J. Invertebr. Pathol. 2015, 132, 1-41.

24. Kongtip, P.; Nankongnab, N.; Kallayanatham, N.; Pundee, R.; Yimsabai, J.; Woskie, S. Longitudinal Study of Metabolic Biomarkers among Conventional and Organic Farmers in Thailand. Int. J. Environ. Res. Public Health 2020, 17, 4178. [CrossRef]

25. Kosamu, I.; Kaonga, C.; Utembe, W. A Critical Review of the Status of Pesticide Exposure Management in Malawi. Int. J. Environ. Res. Public Health 2020, 17, 6727. [CrossRef] [PubMed]

26. DST (Department of Science and Technology). The Bio-Economy Strategy. 2013. Available online: http://www.innovus.co.za/ media/Bioeconomy_Strategy.pdf (accessed on 5 January 2020).

27. Moore, S.D.; Jukes, M.D. Advances in microbial control in IPM: Entomopathogenic Viruses. In Integrated Management of Insect Pests; Kogan, M., Heinrichs, E., Eds.; Burleigh Dodds Science Publishing: Cambridge, UK, 2019; pp. $593-648$.

28. Moore, S.D.; Grout, T.G.; Hattingh, V.; Hofmeyr, J.H. Thresholds and guidelines for intervention against citrus pests. S. Afr. Fruit J. 2008, 7, 77-81.

29. Moore, S.D.; Kirkman, W. Citrus orchard sanitation with emphasis on false codling moth control. S. Afr. Fruit J. 2008, 8, 57-60.

30. van den Bosch, R.; Messenger, P.S.; Gutierrez, A.P. An Introduction to Biological Control; Plenum Press: New York, NY, USA; London, UK, 1982; 247p.

31. van Lenteren, J.C.; Bolckmans, K.; Köhl, J.; Ravensberg, W.J.; Urbaneja, A. Biological control using invertebrates and microorganisms: Plenty of new opp.ortunities. BioControl 2018, 63, 39-59. [CrossRef]

32. Mweresa, C.K.; Mukabana, W.R.; van Loon, J.J.A.; Dicke, M.; Takken, W. Use of semiochemicals for surveillance and control of hematophagous insects. Chemoecology 2020, 30, 277-286. [CrossRef]

33. IAEA. Insect Pest Control: Sterile Insect Technique. Undated. Available online: https://www.iaea.org/topics/sterile-insecttechnique (accessed on 4 December 2020).

34. Klassen, W. Area-wide integrated pest management and the sterile insect technique. In Sterile Insect Technique: Principles and Practices in Area-Wide Integrated Pest Management; Dyck, V.A., Hendrichs, J., Robinson, A.S., Eds.; Springer: Dordrecht, The Netherlands, 2005; pp. 39-68.

35. Knipling, E.F. Possibilities of Insect Control or Eradication Through the Use of Sexually Sterile Males. J. Econ. Entomol. 1955, 48, 459-462. [CrossRef]

36. Barnes, B.N.; Hofmeyr, J.H.; Groenewald, S.; Conlong, D.E.; Wohlfarter, M. The sterile insect technique in agricultural crops in South Africa: A metamorphosis... but will it fly? Afr. Entomol. 2015, 23, 1-18. [CrossRef]

37. Hofmeyr, J.H.; Carpenter, J.E.; Bloem, S. Developing the sterile insect technique for false codling moth: Influence of radiation dose and release ratio on fruit damage and population growth in field cages. J. Econ. Entomol. 2005, 98, 1924-1929.

38. Hofmeyr, J.H.; Hofmeyr, M.; Carpenter, J.E.; Bloem, S.; Slabbert, J.P. Sterile insect releases for control of Thaumatotibia leucotreta (Lepidoptera: Tortricidae): An assessment on semi-commercial scale. Afr. Entomol. 2016, 24, 80-89. [CrossRef]

39. Xsit (X Sterile Insect Technique). 2018. Available online: http:/ /xsit.co.za/our-product/ (accessed on 4 December 2020).

40. Hofmeyr, J.H.; Carpenter, J.E.; Bloem, S.; Slabbert, J.P.; Hofmeyr, M.; Groenewald, S.S. Development of the sterile insect technique to supp.ress false codling moth Thaumatotibia leucotreta (Lepidoptera: Tortricidae) in citrus fruit: Research to implementation (Part 1). Afr. Entomol. 2015, 23, 180-186. [CrossRef]

41. Miller, J.R.; Gut, L.J. Mating Disruption for the 21st Century: Matching Technology with Mechanism. Environ. Entomol. 2015, 44, 427-453. [CrossRef] [PubMed]

42. Miller, J.R.; Gut, L.J.; De Lame, F.M.; Stelinski, L.L. Differentiation of competitive vs. non-competitive mechanisms mediating disruption of moth sexual communication by point sources of sex pheromone (Part I): Theory. J. Chem. Ecol. 2006, 32, 2089-2114. [CrossRef]

43. Miller, J.R.; Gut, L.J.; De Lame, F.M.; Stelinski, L.L. Differentiation of competitive vs. non-competitive mechanisms mediating disruption of moth sexual communication by point sources of sex pheromone (Part 2): Case studies. J. Chem. Ecol. 2006, 32, 2115-2143. [CrossRef] 
44. Hofmeyr, J.H.; Hofmeyr, M. Bestryding van valskodlingmot met paring-ontwrigting. Outspan Citrus Cent. Annual Res. Rep. 1998, 1, 305-311.

45. Hofmeyr, J.H.; Hofmeyr, M. Evaluasie van die paringsontwrigter Isomate vir die kommersiële bestryding van valskoldingmot op nawelbome. Citrus Res. Int. Annu. Res. Rep. 2002, 1, 68-74.

46. Moore, S.D.; Hattingh, V. A review of current Pre-harvest Control Options for False Codling Moth in Citrus in Southern Africa. S. Afr. Fruit J. 2012, 11, 82-85.

47. Steyn, W.P.; Daneel, M.S.; Malan, A.P. Control of Thaumatotibia leucotreta in South African Avocado, Litchi and Macadamia Orchards, Using Entomopathogenic Nematodes. BioControl 2019, 64, 401-411. [CrossRef]

48. AgriIntel. Available online: https://www.agri-intel.com/memeber/login (accessed on 4 December 2020).

49. Moore, S.D. Moths and butterflies: False codling moth (Part 9.4). In Integrated Production Guidelines; Grout, T.G., Ed.; Citrus Research International: Nelspruit, South Africa, 2019; Volume 3, pp. 1-9. Available online: http://www.citrusres.com (accessed on 4 December 2020).

50. El-Sayed, A.M.; Suckling, D.M.; Byers, J.A.; Jang, E.B.; Wearing, C.H. Potential of "lure and kill” in long-term pest management and eradication of invasive species. J. Econ. Entomol. 2009, 102, 815-835. [CrossRef]

51. Jones, O.T. Practical app.lications of pheromones and other semiochemicals (sections 11. Lure and kill). In Insect Pheromones and Their Use in Pest Management; Howse, P., Stevens, I., Jones, O.T., Eds.; Chapman \& Hall: London, UK, 1998; pp. $280-300$.

52. Willers, P.; Holmden, E.; Bedford, E.C.G. An integrated pest control programme for citrus in the Eastern Cape. Farming S. Afr. 1981, 47, 1-7.

53. Moore, S.D. The Development and Evaluation of Cryptophlebia Leucotreta Granulovirus (CrleGV) as a Biological Control Agent for the Management of False Codling Moth, Cryptophlebia leucotreta, on Citrus. Ph.D. Thesis, Rhodes University, Grahamstown, South Africa, 2002.

54. Catling, H.D.; Aschenborn, H. Population studies of the false codling moth, Cryptophlebia leucotreta Meyrick, on citrus in the Transvaal. Phytophylactica 1974, 6, 31-38.

55. Grout, T.G.; Stoltz, K.C.; Tate, B.A. Database of Non-Target Impact Ratings (Similar to Percentage Mortality but Taking Persistence into Account) against Five Key Natural Enemies in Citrus. 2011; Unpublished Report.

56. Schwartz, A. 'n Tegniek vir die massateling van die eierparasiet Trichogrammatoidea luteum Girault, op die eiers van valskodlingmot. Citrus Subtrop. Fruit J. 1977, 526, 5-7.

57. Schwartz, A. Eier-parasiet van valskodlingmot: Evaluasie van ‘n teel- en vrylaatprogram. Citrus Subtrop. Fruit J. 1980, 544, 6-8.

58. Newton, P.J. Movement and impact of Trichogrammatoidea cryptophlebiae Nagaraja (Hymenoptera: Trichogrammatidae) in citrus orchards after inundative releases against the false codling moth, Cryptophlebia leucotreta (Meyrick) (Lepidoptera: Tortricidae). Bull. Entomol. Res. 1988, 78, 85-99. [CrossRef]

59. Newton, P.J.; Odendaal, W.J. Commercial inundative releases of Trichogrammatoidea cryptophlebiae (Hym: Trichogrammatidae) against Cryptophlebia leucotreta (Lepidoptera: Tortricidae) in Citrus. Entomophaga 1990, 35, 545-556. [CrossRef]

60. Moore, S.D.; Hattingh, V. Augmentation of natural enemies for control of citrus pests in South Africa: A guide for growers. S. Afr. Fruit J. 2004, 3, 45-47, 51, 53.

61. Visagie, E. Trichogrammatoidea insectary. In Proceedings of the Fifth National Insect Rearing Workshop; Outspan International: Nelspruit, South Africa, 1997; pp. 25-26.

62. Newton, P.J. False codling moth Cryptophlebia leucotreta (Meyrick). In Citrus Pests in the Republic of South Africa; Bedford, E.C.G., van den Berg, M.A., de Villiers, E.A., Eds.; Dynamic Ad: Nelspruit, South Africa, 1998; pp. 192-200.

63. Moore, S.D.; Richards, G.I.; Chambers, C.; Hendry, D. An improved larval diet for commercial mass rearing of the false codling moth, Thaumatotibia leucotreta (Meyrick) (Lepidoptera: Tortricidae). Afr. Entomol. 2014, 22, 216-219. [CrossRef]

64. Zimba, K.; Hill, M.P.; Moore, S.D.; Heshula, U. Agathis bishopi (Hymenoptera: Braconidae) as a Potential Tool for Detecting Oranges Infested with Thaumatotibia leucotreta (Lepidoptera: Tortricidae). J. Insect Behav. 2015, 28, 618-633. [CrossRef]

65. Zimba, K.; Heshula, U.; Moore, S.D.; Hill, M.P. Host searching and oviposition behaviour of Agathis bishopi (Hymenoptera: Braconidae), a larval parasitoid of false codling moth, Thaumatotibia leucotreta (Lepidoptera: Tortricidae): A potential proxy indicator for fruit infestation. Afr. Entomol. 2016, 24, 524-529. [CrossRef]

66. Zimba, K.; Moore, S.D.; Heshula, U.; Hill, M.P. Agathis bishopi, a larval parasitoid of false codling moth Thaumatotibia leucotreta: Laboratory rearing and effect of adult food on parasitism and longevity. Afr. Entomol. 2016, 24, 153-161. [CrossRef]

67. Samways, M.J.; Grout, T.G.; Prins, A.J. Ants as citrus pests. In Citrus Pests in the Republic of South Africa; Bedford, E.C.G., van den Berg, M.A., de Villiers, E.A., Eds.; Agricultural Research Council: Nelspruit, South Africa, 1998.

68. Samways, M.J.; Nel, M.; Prins, A.J. Ants (Hymenoptera: Formicidae) foraging in citrus trees and attending honeydew-producing Homoptera. Phytophylactica 1982, 14, 155-157.

69. Bedford, E.C.G. The biological control of red scale, Aonidiella aurantii (Mask.), on citrus in South Africa. J. Entomol. Soc. S. Afr. 1968, 31, 1-15.

70. Bownes, A.; Moore, S.D.; Villet, M.H. My enemy's enemies: Recruiting hemipteran-tending generalist ants for biological control in citrus orchards by spatial partitioning of foraging webs. Afr. Entomol. 2014, 22, 519-529. [CrossRef]

71. Samways, M.J.; Buitendag, C.H. Recommendations for control of ants on citrus trees using trunk barriers. Citrus Subtrop. Fruit J. 1986, 624, 9-11. 
72. Nyiira, Z.M. A note on the natural enemies of lepidopterous larvae in cotton bolls in Uganda. Ann. Entomol. Soc. Am. 1970, 63, 1461-1462. [CrossRef]

73. Omer-Cooper, J. Remarks on False Codling Moth; Mimeograph, Rhodes University: Grahamstown, South Africa, 1939 ; pp. 1-17.

74. Seguni, Z.S.K.; Way, M.J.; van Mele, P. The effect of ground vegetation management on competition between the ants Oecophylla longinoda and Pheidole megacephala and implications for conservation biological control. Crop Prot. 2011, 30, 713-717. [CrossRef]

75. Angelini, A.; Amargier, A.; Vandamme, P.; Duthoit, J.L. Une virose á granules chez le lepidoptére Argyroploce leucotreta. Coton Fibres Trop. 1965, 20, 277-282.

76. Komai, F. A taxonomic review of the genus Grapholita and allied genera (Lepidoptera, Tortricidae) in the Palaerctic region. Scand. Entomol. 1999, 55, 1-219.

77. Moore, S.D.; Kirkman, W.; Richards, G.I.; Stephen, P.R. The Cryptophlebia leucotreta granulovirus-10 years of commercial field use. Viruses 2015, 7, 1284-1312. [CrossRef]

78. Jehle, A.J.; Backhaus, H.; Fritsch, E.; Huber, J. Physical map of the Cryptophlebia leucotreta granulosis virus genome and its relationship to the genome of Cydia pomonella granulosis virus. J. Gen. Virol. 1992, 73, 1621-1626. [CrossRef]

79. Mück, O. Biologie, verhalten und wirtshcaftliche bedeutaung von parasiten schädlicher Lepidopteren auf den Kapverden. Neue Entomol. Nachrichten. 1985, 18, 168.

80. Opoku-Debrah, J.K.; Hill, M.P.; Knox, C.; Moore, S.D. Heterogeneity in virulence relationships between Cryptophlebia leucotreta granulovirus isolates and geographically distinct host populations: Lessons from codling moth resistance to CpGV-M. BioControl 2016, 61, 449-459. [CrossRef]

81. Moore, S.D.; Kirkman, W.; Stephen, P. Cryptogran: A virus for the biological control of false codling moth. S. Afr. Fruit J. 2004, 3, 35-39.

82. Hofmeyr, J.H.; Pringle, K.L. Resistance of false codling moth, Cryptophlebia leucotreta (Meyrick) (Lepidoptera: Tortricidae), to the chitin synthesis inhibitor, triflumuron. Afr. Entomol. 1998, 6, 373-375.

83. López-Ferber, M.; Simón, O.; Williams, T.; Caballero, P. Defective or effective? Mutualistic interactions between virus genotypes. Proc. R. Soc. B Biol. Sci. 2003, 270, 2249-2255. [CrossRef]

84. Chambers, C.B.; Opoku-Debrah, J.K.; Moore, S.D. Controlling false codling moth in citrus with a novel Alphabaculovirus, Cryptophlebia peltastica NPV, and a dual isolate Betabaculovirus preparation, Cryptophlebia leucotreta GV. In Proceedings of the 49th Annual Meeting of the Society for Invertebrate Pathology, International Congress on Invertebrate Pathology and Microbial Control, Tours, France, 24-28 July 2016; p. 65.

85. Arthurs, S.P.; Lacey, L.A.; Behle, R.W. Evaluation of lignins and particle films as solar protectants for the granulovirus of the codling moth, Cydia pomonella. Biocontrol Sci. Technol. 2008, 18, 829-839. [CrossRef]

86. Fuller, E.; Elderd, B.D.; Dwyer, G. Pathogen persistence in the environment and insect-baculovirus interactions: Disease-density thresholds, epidemic burnout, and insect outbreaks. Am. Nat. 2012, 179, 70-96. [CrossRef]

87. Shapiro, M.; Farrar, R.R., Jr.; Domek, J.; Javaid, I. Effects of virus concentration and ultraviolet irradiation on the activity of corn earworm and beet armyworm (Lepidoptera: Noctuidae) nucleopolyhedroViruses J. Econ. Entomol. 2002, 95, 243-249. [CrossRef]

88. Mwanza, P. Development of a UV-Tolerant Strain of the South African Isolate of Cryptophlebia Leucotreta Granulovirus for use as an Enhanced Biopesticide for Thaumatotibia leucotreta Control on Citrus. Ph.D. Thesis, Nelson Mandela University, Port Elizabeth, South Africa, 2019; p. 191.

89. Mwanza, P.; Hilliar, S.; Dealtry, G.; Lee, M.; Hill, M.; Moore, S.D. Determination of Reapplication Frequency Required for the Cryptophlebia leucotreta Granulovirus: A Factor of Rate of Virus Breakdown and Larval Behaviour. IOBC-WPRS Bulletin. In Microbial and Nematode Control of Invertebrate Pests; IOBC-WPRS: Riga, Latvia, 2016; pp. 151-154.

90. Marsberg, T.; Jukes, M.D.; Krejmer-Rabalska, M.; Rabalski, L.; Knox, C.; Moore, S.D.; Hill, M.P.; Szewczyk, B. Morphological, genetic and biological characterisation of a novel Alphabaculovirus isolated from Cryptophlebia peltastica (Lepidoptera: Tortricidae). J. Invertebr. Pathol. 2018, 157, 90-99. [CrossRef]

91. Grové, T.; de Villiers, E.A.; Schoeman, P.S. Litchi. In Insects of Cultivated Plants and Natural Pastures in Southern Africa. Pretoria; Prinsloo, G.L., Uys, G.M., Eds.; Entomological Society of Southern Africa: Pretoria, South Africa, 2015; pp. 554-559.

92. Marsberg, T. The Isolation and Genetic Characterisation of a Novel Alphabaculovirus for the Microbial Control of Cryptophlebia peltastica and Closely Related Tortricid Pests. Ph.D. Thesis, Rhodes University, Grahamstown, South Africa, 2016. Available online: http:/ /vital.seals.ac.za:8080/vital/access/manager/Repository/vital:27543 (accessed on 27 January 2021).

93. Marsberg, T.; Jukes, M.; Chambers, C.; Hendriks, C.; Opoku-Debrah, J.; Knox, C.; Hill, M.; Moore, S. The isolation of a novel alphabaculovirus and its potential for microbial control of key tortricid moth pests. In Proceedings of the 16th Meeting of the IOBC-WPRS Working Group: Microbial and Nematode Control of Invertebrate Pests, Tbilisi, Georgia, 11-15 June 2017; Volume 129, pp. 175-178.

94. Hatting, J.L.; Moore, S.D.; Malan, A.P. Microbial control of phytophagous invertebrate pests in South Africa: Current status and future prospects. J. Invertebr. Pathol. 2019, 165, 54-66. [CrossRef]

95. Jukes, M.D. Baculovirus Synergism: Investigating Mixed Alphabaculovirus and Betabaculovirus Infections in the False Codling moth, Thaumatotibia leucotreta, for Improved Pest Control. Ph.D. Thesis, Rhodes University, Grahamstown, South Africa, 2017. Available online: http:/ / hdl.handle.net/10962/61797 (accessed on 27 January 2021). 
96. Jukes, M.D.; Rabalski, L.; Knox, C.M.; Hill, M.P.; Moore, S.D.; Szewczyk, B. Baculovirus synergy: Mixed alphabaculovirus and betabaculovirus infections for the control of Thaumatotibia leucotreta in South Africa. In Proceedings of the 16th Meeting of the IOBC-WPRS Working Group: Microbial and Nematode Control of Invertebrate Pests, Tbilisi, Georgia, 11-15 June 2017; Volume 129, pp. 170-174.

97. Goble, T.A.; Dames, J.F.; Hill, M.P.; Moore, S.D. Investigation of native isolates of entomopathogenic fungi for the biological control of three citrus pests. Biocontrol Sci. Technol. 2011, 21, 1193-1211. [CrossRef]

98. Coombes, C.A.; Hill, M.P.; Moore, S.D.; Dames, J.F.; Fullard, T. Beauvaria and Metarhizium against false codling moth (Lepidoptera:Tortricidae): A step towards selecting isolates for potential development of a mycoinsecticide. Afr. Entomol. 2015, 23, 239-242. [CrossRef]

99. Goble, T.A.; Dames, J.F.; Hill, M.P.; Moore, S.D. The effects of farming system, habitat type and bait type on the isolation of entomopathogenic fungi from citrus soils in the Eastern Cape, South Africa. BioControl 2010, 55, 399-412. [CrossRef]

100. Coombes, C.A.; Hill, M.P.; Moore, S.D.; Dames, J.F.; Fullard, T. Persistence and virulence of promising entomopathogenic fungal isolates for use in citrus orchards in South Africa. Biocontrol Sci. Technol. 2013, 23, 1053-1066. [CrossRef]

101. Coombes, C.A.; Hill, M.P.; Moore, S.D.; Dames, J.F. Entomopathogenic fungi as control agents of Thaumatotibia leucotreta in citrus orchards: Field efficacy and persistence. BioControl 2016, 61, 729-739. [CrossRef]

102. Acheampong, M.A.; Hill, M.P.; Moore, S.D.; Coombes, C.A. UV sensitivity of Beauveria bassiana and Metarhizium anisopliae isolates under investigation as potential biological control agents in South African citrus orchards. Fungal Biol. 2019, 124, 304-310. [CrossRef]

103. Chandler, D. Basic and app.lied research on entomopathogenic fungi. In Microbial Control of Insect and Mite Pests: From Theory to Practice; Lacey, L.A., Ed.; Elsevier: London, UK, 2017; pp. 69-89.

104. Malan, A.P.; Knoetze, R.; Moore, S.D. Isolation and identification of entomopathogenic nematodes from citrus orchards in South Africa and their biocontrol potential against false codling moth. J. Invertebr. Pathol. 2011, 108, 115-125. [CrossRef]

105. Steyn, W.P.; Malan, A.P.; Daneel, M.S.; Slabbert, R.M. Entomopathogenic nematodes from north-eastern South Africa and their virulence against the false codling moth, Thaumatotibia leucotreta (Lepidoptera: Tortricidae). Biocontrol Sci. Technol. 2017, 27, 1265-1278.

106. Malan, A.P.; Moore, S.D. Evaluation of local entomopathogenic nematodes for the control of false codling moth, Thaumatotibia leucotreta (Meyrick, 1913) in a South African citrus orchard. Afr. Entomol. 2016, 24, 489-501. [CrossRef]

107. Steyn, V.M.; Malan, A.P.; Addison, A. Control of false codling moth, Thaumatotibia leucotreta (Lepidoptera: Tortricidae), using in vitro-cultured Steinernema jeffreyense and S. yirgalemense. Biol. Control. 2019. [CrossRef]

108. Moore, S.D.; Ehlers, R.-U.; Manrakhan, A.; Gilbert, M.; Kirkman, W.; Daneel, J.H.; De Waal, J.Y.; Nel, R.; Malan, A.P. Field-scale efficacy of entomopathogenic nematodes to control false codling moth, Thaumatotibia leucotreta (Lepidoptera: Tortricidae), in citrus orchards in South Africa. Crop Prot. 2020. (submitted for publication).

109. Manrakhan, A.; Daneel, J.-H.; Moore, S.D. The impact of naturally occurring entomopathogenic nematodes on false codling moth, Thaumatotibia leucotreta (Lepidoptera: Tortricidae), in citrus orchards. Biocontrol Sci. Technol. 2014, 24, 241-245. [CrossRef]

110. Bathon, H. Impact of Entomopathogenic Nematodes on Non-target Hosts. Biocontrol Sci. Technol. 1996, 6, 421-434. [CrossRef]

111. Ehlers, R.U. Biocontrol nematodes. In Environmental Impacts of Microbial Insecticides; Hokkanen, H.M.T., Hajek, A., Eds.; Kluwer Scientific Publishers: Dortrecht, NL, USA, 2003; pp. 177-220.

112. Grzywacz, D.; Moore, D.; Rabindra, R.J. Mass production of entomopathogens in less industrialized countries. In Mass Production of Beneficial Organisms: Invertebrates and Entomopathogens; Morales-Ramos, J.A., Guadalupe, R.M., Shapiro-Ilan, D.I., Eds.; Academic Press/Elsevier Inc.: London, UK, 2014; pp. 519-561.

113. Daiber, C.C. A study of the biology of the false codling moth [Cryptophlebia leucotreta (Meyr.)]: The cocoon. Phytophylactica 1979, $11,151-157$.

114. Terblanche, J.S.; De Jager, Z.; Boardman, L.; Addison, P. Physiological traits suggest limited diapause response in false codling moth, Thaumatotibia leucotreta (Lepidoptera: Tortricidae). J. Appl. Entomol. 2014, 138, 683-691. [CrossRef]

115. Judd, G.J.R.; Gardiner, M.G.T. Towards eradication of codling moth in British Columbia by complimentary actions of mating disruption, tree banding and sterile insect technique: Five-year study in organic orchards. Crop Prot. 2005, 24, 718-733. [CrossRef]

116. Hufbauer, R.A.; Torchin, M.E. Integrating Ecological and Evolutionary Theory of Biological Invasions. In Biological Invasions; Nentwig, W., Ed.; Springer: Berlin/Heidelberg, Germany, 2008; pp. 79-96.

117. CABI. Invasive Species Compendium: Thaumatotibia leucotreta (False Codling Moth). 2019. Available online: https://www.cabi. org/isc/datasheet/ 6904 (accessed on 27 June 2020).

118. Giliomee, J.H.; Riedl, H. A century of codling moth control in South Africa I. Historical Perspective. J. S. Afr. Soc. Hort. Sci. 1998, $8,27-31$.

119. Wysoki, M. New records of Lepidopterous pests of macadamia in Israel. Phytoparasitica 1986, 14, 147. [CrossRef]

120. Moore, I.D. The Development of the South African Citrus Industry. Agrekon 1962, 1, 6-16. [CrossRef]

121. Chandler, D.; Bailey, A.S.; Tatchell, G.M.; Davidson, G.; Greaves, J.; Grant, W.P. The development, regulation and use of biopesticides for integrated pest management. Philos. Trans. Proc. R. Soc. Lond. B Biol. Sci. 2011, 366, 1987-1998. [CrossRef]

122. Eberle, K.E.; Jehle, J.A.; Hüber, J. Microbial control of crop pests using insect Viruses. In Integrated Pest Management: Principles and Practice; Abrol, D.P., Shankar, U., Eds.; CABI Publishing: Wallingford, UK, 2012; pp. 281-298. 
123. EU (European Union). Directive 2009/128/EC of the European Parliament and of the Council of 21 October 2009 Establishing a Framework for Community Action to Achieve the Sustainable Use of Pesticides. Official Journal of the European Union, L309/71; Publications Office of the European Union: Luxembourg, 2009; Available online: http:/ / data.europa.eu/eli/dir/2009/128/2009-11-25 (accessed on 4 December 2020).

124. EC (European Commission). The Green Deal: Communication from the commission to the European Parliament, the European Council, the Council, the European Economic and Social Committee and the Committee of the Regions. 2019. Available online: https:/ / ec.europa.eu/info/strategy/priorities-2019-2024/european-green-deal_en (accessed on 28 October 2020). 